\title{
Inverse Association of Plasma Level of Glutathione Peroxidase with Liver Fibrosis in Chronic Hepatitis B: Potential Role of Iron
}

\author{
Shirin Moossavi ${ }^{1}$, Sima Besharat ${ }^{1}$, Maryam Sharafkhah ${ }^{1}$, Reza Ghanbari ${ }^{1}$, Amrollah Sharifi ${ }^{2}$, \\ Parisa Rezanejad ${ }^{1}$, Akram Pourshams ${ }^{1}$, Hossein Poustchi ${ }^{1}$, Ashraf Mohamadkhani ${ }^{1 *}$
}

1. Liver and Pancreatobiliary Diseases Research Center, Digestive Diseases Research Institute, Tehran University of Medical Sciences, Tehran, Iran

2. Department of Clinical nutrition, School of Nutritional Sciences and Dietetics, Tehran University of Medical Sciences, Tehran, Iran

\footnotetext{
* Corresponding Author:
}

Ashraf Mohamadkhani PhD, Shariati Hospital, North Amirabad Ave., Tehran 14117, Iran

Tel: + 982182415227

Fax: + 982182415400

Email: mohamadkhani.ashraf@gmail.com

Received: 03 Nov. 2015

Accepted: 21 Feb. 2016

\section{ABSTRACT}

\section{BACKGROUND}

Oxidative stress has a major pathogenic role for liver damage following chronic hepatitis B. Glutathione peroxidase (Gpx) is necessary in oxidative state mechanism that is generally down-regulated by Hepatitis B virus (HBV) infection. On the other hand, disorders of iron homeostasis have been found out in HBV infected patients. Therefore, the objective of this study was to assess the interplay of Gpx and serum iron on clinical and virological features of patients with chronic HBV infection.

\section{METHODS}

One hundred and fifty adult, treatment-naïve, patients with chronic hepatitis $\mathrm{B}$ were randomly designated from an ongoing cohort of patients with HBV. Plasma Gpx1 concentration and HBV DNA quantity were measured. Liver stiffness was measured by transient elastography.

\section{RESULTS}

Serum iron had a positive association with HBV DNA count in the total population. Serum iron was not associated with liver stiffness. However, HBV DNA was significantly associated with liver stiffness only in male patients. Serum Gpx was inversely associated with liver stiffness. Serum iron and Gpx had indirect effects on liver stiffness via HBV DNA count. We observed dissimilar effects of serum iron on HBV DNA and Gpx on liver stiffness in male and female patients.

\section{CONCLUSION}

We identified interplay of serum iron and Gpx 1 in relation to level of liver fibrosis in patients with chronic hepatitis B. Our results propose that oxidative stress and serum iron are differentially implicated in the progression of chronic hepatitis B in male and female patients.

\section{KEYWORDS}

Glutathione peroxidase (Gpx), Hepatitis B, Iron, Liver Stiffness, HBV DNA

Please cite this paper as:

Moossavi S, Besharat S, Sharafkhah M, Ghanbari R, Sharifi A, Rezanejad P, Pourshams A, Poustchi H, Mohamadkhani A. Inverse Association of Plasma Level of Glutathione Peroxidase with Liver Fibrosis in Chronic Hepatitis B: Potential Role of Iron. Middle East J Dig Dis 2016;8:122-130. DOI: 10.15171/mejdd.2016.17

\section{INTRODUCTION}

Chronic hepatitis B (CHB) caused by hepatitis B virus (HBV) is a serious illness and a major etiological factor of liver cirrhosis and hepatocellular carcinoma (HCC). Upon infection, HBV enters the hepatocyte and undergoes replication within the infected hepatocyte. Higher replication rate of the virus leads to sustained inflammation and increased fibrosis. ${ }^{1,2}$ Immune response to 
HBV results in by-production of reactive oxygen species (ROS) including hydrogen peroxide, superoxide anions, and lipid peroxides, which consequently change the oxidative state of the microenvironment. ${ }^{1,3}$ Furthermore, HBV also dynamically regulates the oxidative stress via its HBx (hepatitis B x protein) protein. ${ }^{4,5}$ An imbalance between the production and destruction of ROS results in excess ROS, which induce oxidative damage in cellular components. ${ }^{6}$ Therefore oxidative stress plays a major pathogenic role in liver injury following $\mathrm{CHB}$. It is suggested that the oxidative DNA damage increases the risk of $\mathrm{HBV}$-induced HCC. ${ }^{6}$

Glutathione peroxidase (Gpx) is a family of enzymes that constitute a main antioxidant defense system in mammals. ${ }^{7}$ Gpx 1 is the most abundant Gpx isoenzyme, which is also expressed in the liver. ${ }^{8}$ Gpx 1 is localized to the cytoplasm where it reduces $\mathrm{H} 2 \mathrm{O} 2$ to water by employing glutathione (GSH) as an electron donor. ${ }^{7} \mathrm{Gpx} 1$ is thought to be the most important $\mathrm{H} 2 \mathrm{O} 2$ scavenger. ${ }^{9}$ Previous findings indicate down-regulation of Gpx in HBV transgenic mice. ${ }^{10} \mathrm{HBV}$ transgenic mice have reduced the level of Gpx protein in the liver, which is significantly less than wild type control. The Gpx enzyme activity was also significantly reduced in the liver of HBV transgenic mice compared with controls. Transfection of HBV genome into the human hepatoma cell lines C3A and $\mathrm{HuH}-7$ resulted in decreased protein level of Gpx in C3A cells. ${ }^{11}$ Adenoviral delivery of HBx into Hep3B cell line also results in reduced level of glutathione protein and cell viability following $\mathrm{H} 2 \mathrm{O} 2$ treatment compared with non-transfected cells. ${ }^{4} \mathrm{HBV}$-induced oxidative damage was reviewed elsewhere. ${ }^{3}$ However, the association of serum Gpx1 with HBV progression has not been documented.

Serum iron has been widely studied in viral hepatitis specifically in HCV (Hepatitis C virus) infection. ${ }^{12,13}$ Serum iron, ferritin, and transferrin are significantly different between HBV patients with cirrhosis and healthy controls as well as between patients with and without cirrhosis. Serum iron and ferritin are increased whereas transferrin is decreased in patients with HBV compared with controls. Serum iron and ferritin were positively correlated with serum ALT in cirrhotic patients with HBV. The MELD (Model for End-Stage Liver Disease) score was inversely correlated with serum transferrin in cirrhotic HBV. Serum iron and ferritin was significantly higher in cirrhotic patients with ALT $>40 \mathrm{U} / \mathrm{L}$ whereas serum transferrin was significantly lower. ${ }^{14}$ In a survey of 205 patients with $\mathrm{CHB}$, hepatic iron deposits were found in $35.1 \%$ patients, which were significantly more prevalent in male patients. ${ }^{15}$ The interaction of serum iron and Gpx1 in oxidative-induced injury has been studied in mouse astrocyte. ${ }^{16}$ The interplay of serum iron and Gpx in HBV infection is not known. Therefore, the main objective of the present study was to evaluate the interplay of Gpx and serum iron on clinical and virological characteristics of patients with chronic HBV.

\section{MATERIALS AND METHODS}

\section{Patients}

One hundred and fifty adult, treatment-naïve, patients with $\mathrm{CHB}$ defined as being HBsAg positive and HBeAg negative according to current guidelines were randomly selected from 3505 participants of HBV cohort. ${ }^{17,18}$ The patients did not have co-infection with human immune-deficiency virus (HIV), hepatitis $\mathrm{C}$ virus, hepatitis $\mathrm{D}$ virus, and hepatitis G virus. They were not pregnant, and did not have autoimmune hepatitis, history of alcohol consumption, recent blood transfusion, and hemochromatosis. The patients had not received oral or intravenous iron-containing drugs, steroid, pegylated interferon, or nucleoside analog therapy at the time of the sample collection. Written informed consent was obtained from all the individuals. The study was conducted according to the Declaration of Helsinki. The Institutional Review Board and the Ethics Committee of the Digestive Disease Research institute approved the study protocol.

\section{Study Design}

At the first visit, demographic data of the participants were recorded. Liver stiffness was assessed by transient elastography, and $10 \mathrm{ml}$ peripheral venous blood was collected. Sera and plasma samples were stored at $-70^{\circ} \mathrm{C}$ until further processing.

\section{Glutathione Peroxidase Measurement}

Glutathione Peroxidase concentration was measured in the plasma samples by enzyme-linked immunosorbent assay (ELISA) using the Human Glutathione Peroxidase 1 ELISA Kit (BIOVENDOR-LABORATORNI 
MEDICINA A.S. Hong Kong, China) according to the manufacturer's instructions. The lower limit of detection of the kit is $45 \mathrm{pg} / \mathrm{mL}$.

\section{HBV-DNA Quantification}

HBV DNA was extracted from $200 \mu \mathrm{L}$ of plasma using QIAamp DNA Blood Mini Kit (QIAGEN, Valencia, CA, USA) and then quantified in the Light-Cycler (Roche Diagnostics, Mannheim, Germany) by the artus RealArt ${ }^{\mathrm{TM}}$ HBV LC PCR (QIAGEN, Hilden, Germany) according to the manufacturer's instructions. The linear range of this assay was $2 \times 10^{1}-10^{8} \mathrm{IU} / \mathrm{mL}$.

\section{Liver Stiffness Measurement}

Liver stiffness was measured by a trained medical doctor using the FibroScan ${ }^{\circledR} 502$ machine (EchoSense, Paris, France, $5 \mathrm{MHz}$ ) following at least 3 hours fasting. According to the manufacturer's guidelines the M and XL probes were used for individuals with thoracic perimeter of less than or above $110 \mathrm{~cm}$, respectively. With the patient lying in the dorsal decubitus position with maximal abduction of the right arm, the probe was placed on the skin overlying the right lobe of the liver, through the intercostal spaces. At least 10 measurements were done for each patient and the median value was recorded. Values were considered valid if the interquartile range (IQR) was less than $30 \%$ of the median reading and the success rate was at least $60 \%$. The median value was calculated automatically and expressed in kilopascals $(\mathrm{kPa})$. Transient elastography was not performed in cases of any degree of ascites, ferromagnetic tools in the body, pregnancy, or morbid obesity as suggested by the manufacturer. Cut-off for the advanced liver fibrosis was set as equal or greater than $8 \mathrm{KPa}$.

\section{Statistical Analysis}

Statistical analysis was performed using the Stata software version 12 (Stata Statistical Software: Release 12. College Station, TX: StataCorp LP). Data were expressed as mean \pm SD and number (percent) for continues and categorical data, respectively. Baseline characteristics were tested between male and female patients using independent $\mathrm{t}$ test or Chi-square test, as appropriate. Simple linear regression analysis was used to determine the probable risk factors of HBV DNA count and liver stiffness. Also, Pearson correlation was calculated to determine the linear relations between continuous variables. In order to examine the strength of direct and indirect associations among variables, path regression analysis was used, which measures the causal association of the variables in a hypothesized system. P value of less than 0.05 was considered as statistically significant.

\section{RESULTS}

Overall, 150 patients with CHB (65 [43.3\%] male) with the mean $\pm \mathrm{SD}$ age of $59.2 \pm 7.0$ years were investigated. Log HBV DNA count and liver stiffness were $2.98 \pm 1.05$ and $5.16 \pm 2.24 \mathrm{kPa}$, respectively. The mean concentrations of serum iron and Gpx were 69.31 \pm 25.96 $\mu \mathrm{g} / \mathrm{dL}$ and $2.33 \pm 2.87 \mathrm{ng} / \mathrm{mL}$, respectively. The baseline characteristics of patients are summarized in table 1 . Overall, 129 (86\%) patients had mild fibrosis, 14 (9\%) had moderate fibrosis, and 7 (5\%) had advanced liver fibrosis on liver stiffness measurement. The levels of Gpx, serum iron, and HBV DNA in different stages of liver fibrosis are summarized in table 2.

\section{Association of Serum Iron with HBV DNA Count}

We measured the association between the patients' features and HBV DNA count. Serum iron had a positive association with HBV DNA count in the total population. Increasing each $\mu \mathrm{g} / \mathrm{dL}$ of serum Iron added 0.01 to the HBV DNA log count $[p=0.002,95 \%$ CI: (0.004 to 0.017$)]$. We also observed a negative association between serum Gpx and HBV DNA log count, albeit it was not statistically significant $[p=0.05,-0.06(-0.12$ to 0.001$)]$. We did not detect an interaction between sex and either serum iron or Gpx on the HBV DNA. Therefore, we did not observe a significant difference between the association of serum iron or Gpx on HBV DNA in men and women (figure 1).

\section{Determinant Factors of Liver Stiffness}

We also measured the association between the patients' features and liver stiffness. Serum iron was not associated with liver stiffness, however, HBV DNA count was positively associated with it $[p=0.006,0.48$ (0.14 to 0.82$)]$. The effect of HBV DNA on liver stiffness was significantly different between male and female patients ( $p$ for interaction=0.018). HBV DNA was significantly associated with liver stiffness only 
Table 1: Baseline characteristics of the patients

\begin{tabular}{lccc}
\hline Feature & Male & Female & Total \\
\hline $\mathrm{N}(\%)$ & $65(43.33)$ & $85(56.67)$ & 150 \\
\hline Age, mean $\pm \mathrm{SD}$ & $58.88 \pm 7.78$ & $59.52 \pm 6.39$ & $59.24 \pm 7.01$ \\
\hline Smoking, $\mathrm{n}(\%)$ & & & \\
\hline No & $12(18.5)$ & $18(21.18)$ & $120(80.00)$ \\
\hline Yes & $53(81.54)$ & $67(78.82)$ & $30(20.00)$ \\
\hline Body mass index ${ }^{*}$, mean $\pm \mathrm{SD}$ & $27.04 \pm 4.65$ & $29.66 \pm 5.09$ & $28.55 \pm 5.06$ \\
\hline Hb $/ \mathrm{dL}{ }^{*}$, mean $\pm \mathrm{SD}$ & $14.02 \pm 1.49$ & $12.31 \pm 1.35$ & $13.05 \pm 1.64$ \\
\hline ALT U/L, mean $\pm \mathrm{SD}$ & $32.54 \pm 48.43$ & $24.88 \pm 33.08$ & $28.20 \pm 40.48$ \\
\hline AST U/L, mean $\pm \mathrm{SD}$ & $27.82 \pm 28.94$ & $24.11 \pm 19.29$ & $25.71 \pm 23.94$ \\
\hline ALP U/L, mean $\pm \mathrm{SD}$ & $267.31 \pm 67.37$ & $272.06 \pm 99.30$ & $270.00 \pm 86.68$ \\
\hline Creatinine mg/dL ${ }^{*}, \mathrm{mean} \pm \mathrm{SD}$ & $1.27 \pm 0.42$ & $1.02 \pm 0.21$ & $1.13 \pm 0.34$ \\
\hline Serum Iron $\mu \mathrm{g} / \mathrm{dL}{ }^{*}, \mathrm{mean} \pm \mathrm{SD}$ & $76.69 \pm 26.78$ & $63.66 \pm 23.97$ & $69.31 \pm 25.96$ \\
\hline Glutathione peroxidase $\mathrm{ng} / \mathrm{mL}, \mathrm{mean} \pm \mathrm{SD}$ & $2.14 \pm 2.46$ & $2.47 \pm 3.15$ & $2.33 \pm 2.87$ \\
\hline HBV DNA log $(\mathrm{IU} / \mathrm{mL}), \mathrm{median}(\mathrm{IQR})$ & $3.05 \pm 1.13$ & $2.92 \pm 0.99$ & $2.98 \pm 1.05$ \\
\hline Fibroscan score $(\mathrm{kPa})$, median $(\mathrm{IQR})$ & $5.51 \pm 2.67$ & $4.89 \pm 1.82$ & $5.16 \pm 2.24$ \\
\hline
\end{tabular}

HB, hemoglobin; ALT, alanine aminotransferase; AST, aspartate aminotransferase; ALP, alkaline phosphatase; HBV, hepatitis B virus; IQR, interquartile range " These variables were significantly different between male and female patients $(p<0.05)$

Table 2: Association of serum iron, serum Gpx, and HBV DNA count with liver stiffness

\begin{tabular}{cccccc}
\hline Liver stiffness & Fibrosis & N (\%) & HBV DNA & Serum iron & Gpx \\
\hline $0<$ liver stiffness $<7$ & Mild & $129(86 \%)$ & $2.84 \pm 0.88$ & $68.65 \pm 25.26$ & $2.46 \pm 3.00$ \\
\hline $7 \leq$ liver stiffness $<8$ & Moderate & $14(9 \%)$ & $3.48 \pm 1.47$ & $66.36 \pm 27.29$ & $1.97 \pm 1.87$ \\
\hline $8 \leq$ liver stiffness & Sever & $7(5 \%)$ & $4.54 \pm 1.53$ & $87.28 \pm 33.28$ & $0.61 \pm 0.39$ \\
\hline
\end{tabular}

in men $[p=0.003,0.87(0.31$ to $1.42 ; p=0.003)]$ and not women $[p=0.750,0.06$ ( 0.33 to 0.46$)]$. Serum Gpx was inversely associated with liver stiffness $[p=0.009$, $-0.17(-0.29$ to -0.04$)]$ with no significant interaction between sex and Gpx ( $p$ for interaction=0.398). However, in the subgroup analysis, the association between Gpx and liver stiffness was not statistically significant in men possibly because of the small sample size. We did not distinguish a significant association between serum iron and liver stiffness (figure 2). More over we did not detect significant associations between age, sex, and smoking and HBV DNA level and liver stiffness. BMI was positively associated with liver stiffness in women. However, the interaction of BMI and sex was not significant. This might be due to the significantly higher BMI in women in our study (data not shown).

Interplay of Serum Iron, HBV DNA, and Serum GPx

The directed and undirected dependencies of serum iron, HBV DNA, and Gpx on liver stiffness were ana- lyzed by path analysis. We identified that serum iron was positively associated with HBV DNA log count [ $p=0.002 ; 0.01(0.003$ to 0.016$)]$. Serum Gpx was inversely associated with HBV DNA, albeit not significantly. We also identified that liver stiffness had positive association with HBV DNA $[p=0.013 ; 0.42(0.09$ to 0.75$)]$ but negative with $\mathrm{Gpx}[p=0.022 ;-0.14(-0.26$ to -0.02)]. Serum iron and Gpx had indirect effects on liver stiffness via HBV DNA count $[P=0.056 ; 0.004$ ( 0.000 to 0.008$)]$ and $[p=0.175 ;-0.02(-0.05$ to 0.01$)]$, respectively. Consequently, the combined direct and indirect effect of Gpx on liver stiffness was [-0.16 (-0.28 to $-0.04), p=0.009]$. We observed distinct effects of serum iron on HBV DNA and Gpx on liver stiffness in men and women. Serum iron was significantly associated with HBV DNA in men [ $p=0.010 ; 0.01(0.003$ to 0.02$)]$ while Gpx demonstrated a significant inverse association with liver stiffness in women $[p=0.035 ;-0.13(-0.25$ to $-0.01)$ ]. We also observed a positive trend in the indirect 
Table 3: Interplay of serum Iron, HBV DNA, and serum GPx in path analysis

\begin{tabular}{lcccc}
\hline \multirow{2}{*}{ Factors } & \multicolumn{2}{c}{ Male } & \multicolumn{2}{c}{ Female } \\
\cline { 2 - 5 } & RC $(95 \% \mathrm{CI})$ & $p$-value & RC $(95 \% \mathrm{CI})$ & $p$-value \\
\hline Associated with HBV DNA count & & & \\
\hline Serum Iron & $0.01(0.003$ to 0.02$)$ & 0.010 & $0.01(-0.01$ to 0.02$)$ & 0.069 \\
\hline Factors associated with liver stiffness & & & \\
\hline BMI & $0.03(-0.09$ to 0.16$)$ & 0.593 & $0.08(0.01$ to 0.16$)$ & 0.022 \\
\hline HBV DNA & $0.82(0.29$ to 1.35$)$ & 0.003 & $0.002(-0.37$ to 0.38$)$ & 0.990 \\
\hline Gpx & $-0.19(-0.43$ to 0.06$)$ & 0.131 & $-0.13(-0.25$ to -0.01$)$ & 0.035 \\
\hline
\end{tabular}

effect of serum iron on liver stiffness in men $[p=0.051$; 0.01 (0.000 to 0.021$)$ ] (table 3 ). The pathway diagram is illustrated in figure 3 .

\section{DISCUSSION}

Oxidative stress and serum iron are independently implicated in the pathogenesis of CHB. There is currently no report on the interplay of Gpx and serum iron on HBV DNA and liver fibrosis. We assessed the plasma concentration of Gpx and serum iron in 150 patients with CHB. We did not histologically assess the liver iron deposit, as liver biopsy specimens were not available for the patients. However, we had previously demonstrated the correlation of transient elastography with histological measure of hepatic iron deposition. ${ }^{2,19,20}$ Therefore, we used the liver stiffness as an indirect measure of both liver fibrosis and liver iron deposit. We demonstrated that plasma level of Gpx was inversely associated with HBV DNA count and liver stiffness whereas serum iron was positively associated with HBV DNA count and was indirectly affecting the liver stiffness. The effect of serum iron on HBV DNA and HBV DNA on liver stiffness was affected by sex. Interestingly, HBV DNA was significantly associated with liver stiffness only in men. In the multivariate path analysis, which relies on the causal relationship of the investigated factors, it was confirmed that serum iron indirectly affected the liver stiffness via its effect on HBV DNA while Gpx1 both directly and indirectly regulated the liver stiffness.

Oxidative stress plays a major pathogenic role in liver injury following $\mathrm{CHB} .{ }^{21,22} \mathrm{HBx}$ protein of $\mathrm{HBV}$ renders hepatocytes more sensitive to $\mathrm{H} 2 \mathrm{O} 2$-induced cell death ${ }^{4}$ by reducing the liver Gpx content as well as activity. ${ }^{11} \mathrm{We}$ did not compare the serum level of Gpx in patients with
CHB with healthy controls. However, we identified an inverse association between serum Gpx concentration and the degree of liver fibrosis. Higher concentration of serum Gpx was detected in patients with lower stages of liver fibrosis. On the other hand, serum iron was identified as an independent predictive factor of HBV DNA count. However, we did not detect a significant association between serum iron and liver stiffness in the path analysis. In other words, although the serum iron is important in regulating the oxidative response in the course of HBV infection, its overall effect is mediated by the regulation of HBV DNA replication and hence, DNA count. The association between HBV DNA and fibrosis had been previously demonstrated. ${ }^{23,24}$

The results on the association of serum and liver iron on the progression of viral hepatitis are contradictory. Earlier studies have demonstrated that iron homeostasis is disrupted in HBV infected patients leading to increased serum iron as well as hepatic iron deposition. ${ }^{5,25-27}$ Patients with CHB and cirrhosis have significantly higher level of serum iron compared with those without cirrhosis. ${ }^{14}$ Similarly, serum ferritin is significantly higher in CHB patients with progressive liver disease (and not the asymptomatic carriers) compared with healthy controls..$^{28}$ Hepatic iron content was also higher in patients with $\mathrm{CHB}$ and higher grades of fibrosis and higher stages, albeit not significantly. ${ }^{29,18}$ However, in other reports, serum iron and ferritin were not different between cirrhotic and non-cirrhotic patients with $\mathrm{CHB}^{30}$ and were not associated with histological assessment of liver fibrosis. ${ }^{28}$ In chronic hepatitis $\mathrm{C}$, fibrosis staging is also positively correlated with higher hepatic iron content. ${ }^{29}$ Serum ferritin and transferrin saturation are significantly increased in $\mathrm{CHC}$ with cirrhosis compared with non-cirrhosis. ${ }^{31}$ The 

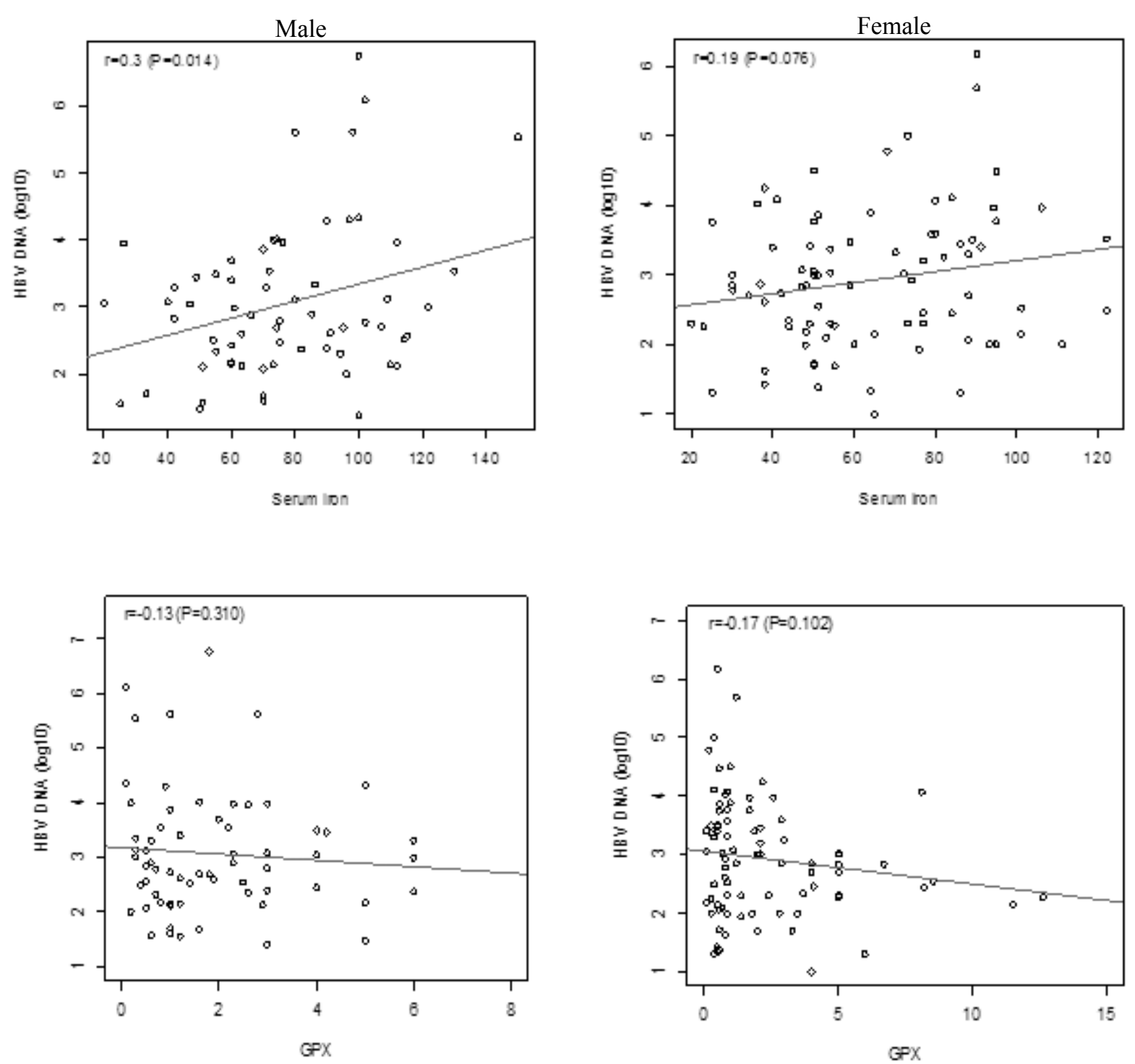

Fig. 1: Association of serum iron and Gpx with HBV DNA count in patients with chronic HBV.

association of cell-specific hepatic iron deposit was assessed in CHC in relation to adverse clinical events including death, hepatocellular carcinoma, decompensated cirrhosis, and increased liver fibrosis. Iron content of hepatocytes and portal triads were significantly associated with the rate of an adverse clinical event. Serum ferritin and transferrin saturation were also associated with the poor outcome but not significantly. However, serum iron was a significant predictor of an adverse outcome. ${ }^{32}$ Negative association of iron measures with fibrosis has also been reported in $\mathrm{CHC}^{33}$

Iron is a hepatotoxic agent, which can affect liver ho- meostasis and promote non-hemochromatic liver diseases. It is known that $\mathrm{Hbx}$ suppresses the Gpx production and reduces the Gpx activity in the liver, as a consequence of which the HBV-infected liver becomes more susceptible to oxidative stress. Concurrent high levels of serum and/ or liver iron now can augment the injury and hence, result in hepatitis progression to advanced stages of fibrosis and ultimately cirrhosis. HBV-induced oxidative stress could induce stimulation of hepatic stellate cell, proliferation of myofibroblasts, formation of extracellular matrix, and consequently augmentation of fibrogenesis. ${ }^{34}$ Moreover, oxidative imbalance could cause DNA damage, which 

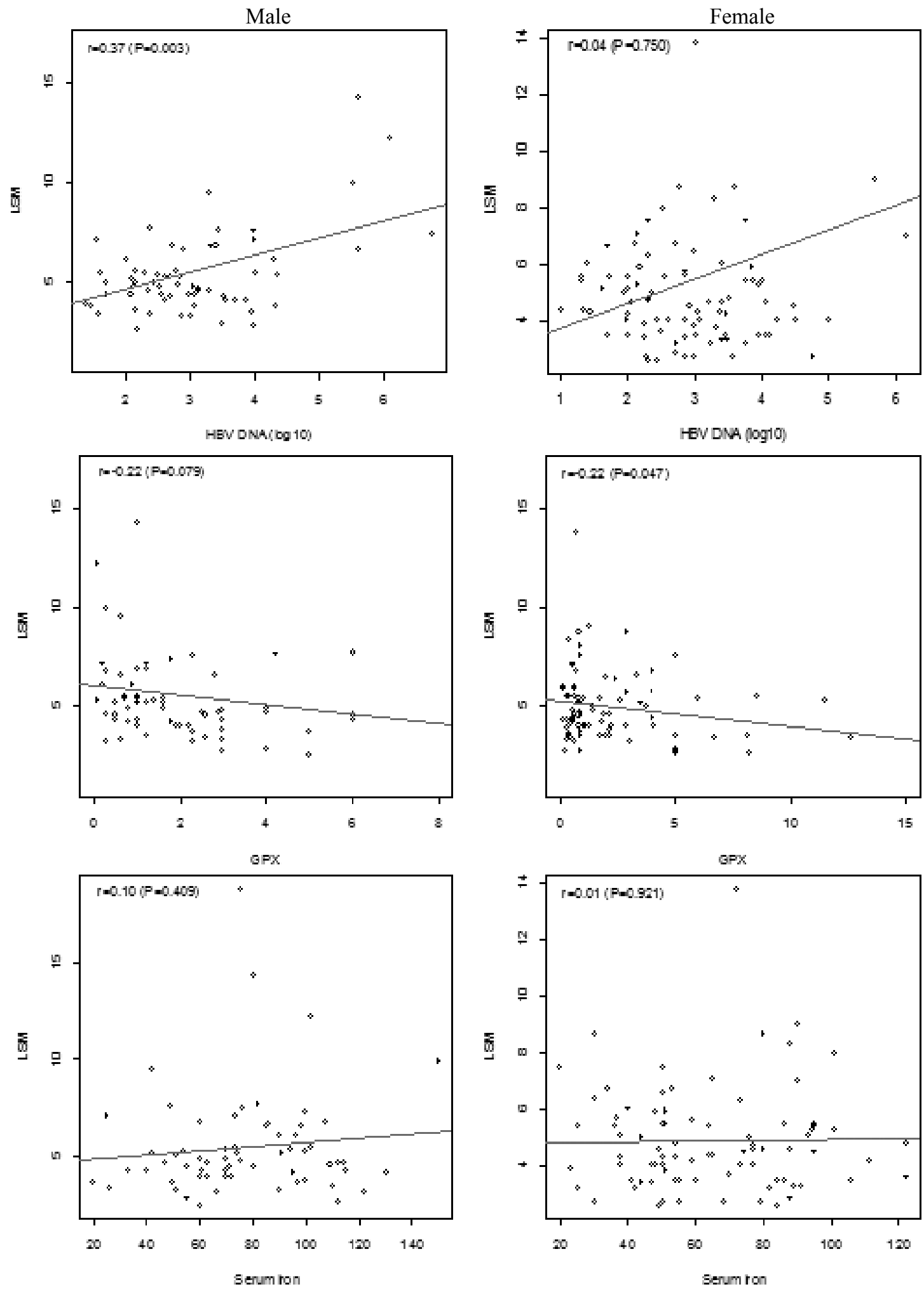

LSM (liver stiffness measurement)

Fig. 2: Association of serum iron, HBV, Gpx on liver stiffness measurement in patients with chronic HBV. 


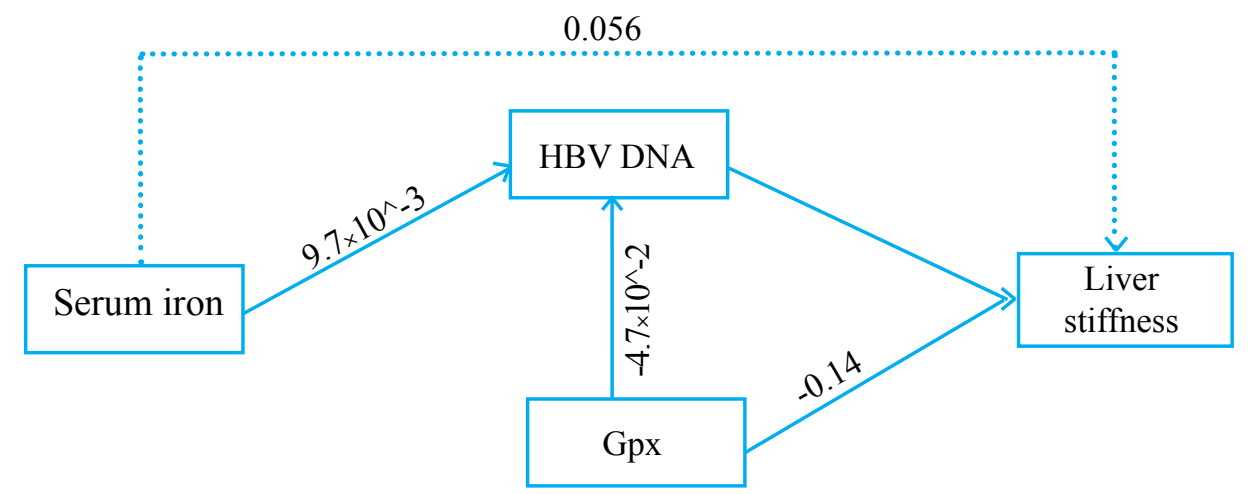

Fig. 3: The interaction of serum iron, HBV DNA, and Gpx on liver stiffness.

upon failure of the repair mechanisms can become fixated and result in potentially oncogenic mutations. ${ }^{35}$ Currently, anti-oxidants such as N-acetylcysteine, S-adenosyl-Lmethionine, and vitamin E are utilized as supplementary medications in patients who have developed fibrosis. ${ }^{36}$ We identified interplay of serum iron and Gpx1 in relation to level of liver fibrosis in CHB. It is conceivable that measures, which aim at targeting the ROS imbalance and hence reducing the oxidative stress in $\mathrm{HBV}$-infected liver, could have therapeutic benefits for patients with $\mathrm{CHB}$ in terms of preventing the progressive liver damage, fibrosis, and ultimately cirrhosis.

\section{ACKNOWLEDGEMENT}

This study was supported in part by a grant from Digestive Disease Research Institute, Tehran University of Medical Sciences.

\section{CONFLICT OF INTEREST}

The authors declare no conflict of interest related to this work.

\section{REFERENCES}

1. McMahon BJ. Chronic hepatitis B virus infection. Med Clin North Am 2014;98:39-54. doi:10.1016/j.mcna.2013. 08.004

2. Besharat S, Poustchi H, Mohamadkhani A, Katoonizadeh A, Moradi A, Roshandel G, et al. Association of Mutations in the Basal Core Promoter and Pre-core Regions of the Hepatitis B Viral Genome and Longitudinal Changes in HBV Level in $\mathrm{HBeAg}$ Negative Individuals: Results From a Cohort Study in Northern Iran. Hepat Mon 2015;15:e23875. doi: 10.5812/hepatmon.23875

3. Higgs MR, Chouteau P, Lerat H. 'Liver let die': oxidative DNA damage and hepatotropic viruses. J Gen Virol 2014;95:991-1004.
4. Wu YL, Wang D, Peng XE, Chen YL, Zheng DL, Chen WN, et al. Epigenetic silencing of $\operatorname{NAD}(\mathrm{P})$ $\mathrm{H}$ :quinone oxidoreductase 1 by hepatitis $\mathrm{B}$ virus $\mathrm{X}$ protein increases mitochondrial injury and cellular susceptibility to oxidative stress in hepatoma cells. Free Radic Biol Med 2013;65:632-644. doi:10.1016/j.freeradbiomed.2013.07.037

5. Gu JM, Lim SO, Oh SJ, Yoon SM, Seong JK, Jung G. $\mathrm{HBx}$ modulates iron regulatory protein 1-mediated iron metabolism via reactive oxygen species. Virus Res 2008;133:167-177. doi:10.1016/j.virusres.2007.12.014

6. Nair J, Srivatanakul P, Haas C, Jedpiyawongse A, Khuhaprema T, Seitz HK, et al. High urinary excretion of lipid peroxidation-derived DNA damage in patients with cancer-prone liver diseases. Mutat Res 2010;683:23-28. doi:10.1016/j.mrfmmm.2009.10.002

7. Espinoza SE, Guo H, Fedarko N, DeZern A, Fried LP, Xue QL, et al. Glutathione peroxidase enzyme activity in aging. J Gerontol A Biol Sci Med Sci 2008;63:505-509.

8. Petryszak R, Burdett T, Fiorelli B, Fonseca NA, Gonzalez-Porta M, Hastings E, et al. Expression Atlas update--a database of gene and transcript expression from microarray- and sequencing-based functional genomics experiments. Nucleic Acids Res 2014;42:D926-932.

9. Muller FL, Lustgarten MS, Jang Y, Richardson A, Van Remmen H. Trends in oxidative aging theories. Free Radic Biol Med 2007;43:477-503. doi:10.1016/j.freeradbiomed.2007.03.034

10. Lee DH, Esworthy RS, Chu C, Pfeifer GP, Chu FF. Mutation accumulation in the intestine and colon of mice deficient in two intracellular glutathione peroxidases. Cancer Res 2006;66:9845-9851. doi: 10.1158/0008-5472.CAN06-0732

11. Wang Q, Na B, Ou JH, Pulliam L, Yen TS. Hepatitis B virus alters the antioxidant system in transgenic mice and sensitizes hepatocytes to Fas signaling. PLoS One 2012;7:e36818. doi: 10.1371/journal.pone.0036818

12. Vagu C, Sultana C, Ruta S. Serum iron markers in patients with chronic hepatitis C infection. Hepat Mon 2013;13:e13136. doi: 10.5812/hepatmon.13136

13. Mifuji-Moroka R, Iwasa M, Miyachi H, Sugimoto R, Tanaka H, Ishihara T, et al. Iron overload and glucose 
abnormalities in chronic hepatitis $\mathrm{C}$ virus infection: phlebotomy lowers risk of new-onset diabetes. Hepatogastroenterology 2013;60:1736-41.

14. Mao W, Hu Y, Lou Y, Chen Y, Zhang J. Abnormal serum iron markers in chronic hepatitis $\mathrm{B}$ virus infection may be because of liver injury. Eur $J$ Gastroenterol Hepatol 2015;27:130-136. doi: 10.1097/MEG. 0000000000000247

15. Sebastiani G, Tempesta D, Alberti A. Hepatic iron overload is common in chronic hepatitis B and is more severe in patients coinfected with hepatitis D virus. $J$ Viral Hepat 2012;19:e170-176. doi: 10.1111/j.1365-2893.2011. 01508.x

16. Liddell JR, Hoepken HH, Crack PJ, Robinson SR, Dringen R. Glutathione peroxidase 1 and glutathione are required to protect mouse astrocytes from iron-mediated hydrogen peroxide toxicity. J Neurosci Res 2006;84:578586. doi: 10.1002/jnr.20957

17. Poustchi H, Katoonizadeh A, Ostovaneh MR, Moossavi S, Sharafkhah M, Esmaili S, et al. Cohort profile: golestan hepatitis B cohort study- a prospective long term study in northern iran. Middle East J Dig Dis 2014;6:186-94.

18. Pourshams A, Nasiri J, Mohammadkhani A, Nasrollahzadeh D. Hepatitis B in Gonbad-Kavoos: prevalence, risk factors and intrafamilial spreading. Govaresh 2004;9:222-5.

19. Hamidieh AA, Shazad B, Ostovaneh MR, Behfar M, Tayebi S, Malekzadeh R, et al. Noninvasive measurement of liver fibrosis using transient elastography in pediatric patients with major thalassemia who are candidates for hematopoietic stem cell transplantation. Biol Blood Marrow Transplant 2014;20:1912-7. doi: 10.1016/j.bbmt. 2014.07.025

20. Poustchi H, Eslami M, Ostovaneh MR, Modabbernia A, Saeedian FS, Taslimi S, et al. Transient elastography in hepatitis $\mathrm{C}$ virus-infected patients with beta-thalassemia for assessment of fibrosis. Hepatol Res 2013;43:12761283. doi: 10.1111/hepr.12088

21. Dandri M, Burda MR, Burkle A, Zuckerman DM, Will H, Rogler CE, et al. Increase in de novo HBV DNA integrations in response to oxidative DNA damage or inhibition of poly(ADP-ribosyl)ation. Hepatology 2002;35:217223. doi: 10.1053/jhep.2002.30203

22. Mohamadkhani A, Katoonizadeh A, Poustchi H. Immune-Regulatory Events in the Clearance of HBsAg in Chronic Hepatitis B: Focuses on HLA-DP. Middle East J Dig Dis 2015;7:5-13.

23. Mohamadkhani A, Sayemiri K, Ghanbari R, Elahi E, Poustchi H, Montazeri G. The inverse association of serum HBV DNA level with HDL and adiponectin in chronic hepatitis B infection. Virol J 2010;7:228. doi: 10.1186/1743-422X-7-228

24. Bai H, Liu H, Chen X, Xu C, Dou X. Influence of age and $\mathrm{HBeAg}$ status on the correlation between HBV DNA and hepatic inflammation and fibrosis in chronic hepatitis B patients. Dig Dis Sci 2013;58:1355-1362.

25. Felton C, Lustbader ED, Merten C, Blumberg BS. Serum iron levels and response to hepatitis B virus. Proc Natl Acad Sci USA 1979;76:2438-2441.

26. Patil PS, Mohandas KM, Bhatia SJ, Mehta SA. Serum ferritin and the risk of hepatocellular carcinoma in chronic liver disease of viral etiology: a case-control study. Indian J Gastroenterol 2014;33:12-18.

27. Di Bisceglie AM, Axiotis CA, Hoofnagle JH, Bacon BR. Measurements of iron status in patients with chronic hepatitis. Gastroenterology 1992;102:2108-2113.

28. Ghaziani T, Alavian SM, Zali MR, Shahraz S, Agah M, Jensen KP, et al. Serum measures of iron status and HFE gene mutations in patients with hepatitis $\mathrm{B}$ virus infection. Hepatol Res 2007;37:172-178. doi: 10.1111/j.1872034X.2007.00026.X

29. Fujita N, Sugimoto R, Urawa N, Araki J, Mifuji R, Yamamoto $\mathrm{M}$, et al. Hepatic iron accumulation is associated with disease progression and resistance to interferon/ribavirin combination therapy in chronic hepatitis C. J Gastroenterol Hepatol 2007;22:1886-1893. doi: 10.1111/j.1440-1746.2006.04759.x

30. Chook JB, Ngeow YF, Yap SF, Tan TC, Mohamed R. Combined use of wild-type HBV precore and high serum iron marker as a potential tool for the prediction of cirrhosis in chronic hepatitis B infection. J Med Virol 2011;83:594-601.

31. Weiss G, Umlauft F, Urbanek M, Herold M, Loyevsky M, Offner F, et al. Associations between cellular immune effector function, iron metabolism, and disease activity in patients with chronic hepatitis $\mathrm{C}$ virus infection. $J$ Infect Dis 1999;180:1452-8. doi: $10.1086 / 315052$

32. Lambrecht RW, Sterling RK, Naishadham D, Stoddard AM, Rogers T, Morishima C, et al. Iron levels in hepatocytes and portal tract cells predict progression and outcomes of patients with advanced chronic hepatitis C. Gastroenterology 2011;140:1490-1500 e1493.

33. Won JE, Jeong SH, Chung JI, Lee JH, Hwang SH, Kim $\mathrm{JW}$, et al. Hepatic iron, serum ferritin, HFE mutation, and hepatic fibrosis in chronic hepatitis C. Intervirology 2009;52:239-46. doi : 10.1159/000228547

34. Bhogal RH, Curbishley SM, Weston CJ, Adams DH, Afford SC. Reactive oxygen species mediate human hepatocyte injury during hypoxia/reoxygenation. Liver Transpl 2010;16:1303-1313. doi: 10.1002/lt.22157

35. Tanaka H, Fujita N, Sugimoto R, Urawa N, Horiike S, Kobayashi $\mathrm{Y}, \mathrm{t}$ al. Hepatic oxidative DNA damage is associated with increased risk for hepatocellular carcinoma in chronic hepatitis C. Br J Cancer 2008;98:580-6. doi:10.1038/sj.bjc.6604204

36. Ghiassi-Nejad Z, Friedman SL. Advances in antifibrotic therapy. Expert Rev Gastroenterol Hepatol 2008;2:803816. doi: $10.1586 / 17474124.2 .6 .803$ 